\title{
The Impact of Health, Education and Development of MSMEs on Gross Regional Domestic Product (PDRB) in Regional Provinces Special Yogyakarta Period 2010 - 2019
}

\author{
Senen ${ }^{1}$, Firdaus Budhy Saputro ${ }^{2}$ \\ \{dosen0188@unpam.ac.id ${ }^{1}$,ovier2008@gmail.com²\} \\ Pamulang University, South Tangerang, Banten, Indonesia ${ }^{1}$, \\ University of Indraprasta PGRI, Jakarta, Indonesia ${ }^{2}$
}

\begin{abstract}
This study aims to identify, review, analyze, find, and describe the influence of health index, education index, and MSME development on economic growth. The research methods used in this study are quantitative with tiered regression analysis techniques for cross-section and time-series data. The study results simultaneously stated that the health index, education index, and development of MSMEs influence the PDRB of DIY Province. The results showed that the education index significantly and positively affected the economic growth of DIY Province. In contrast, the health and development index of MSMEs partially did not affect economic growth.
\end{abstract}

Keywords: Health Index; Education Index; MSME Development; PDRB

\section{Introduction}

Monetary formation is the process of continuously improving a country's economic conditions over a period of time. If economic activity is higher than it was in the prior time, the economy is considered to be experiencing a change in development. The rate of economic growth determines the success of a region's development. As a result, each region's planning and development goals always include a high rate of economic growth [1]. The primary criterion for the continuation of economic development is high and sustainable economic growth. Economic growth is defined as "a country's ability to offer growing economic benefits to its population and the extension of this capability." is based on technological and institutional advances and the ideological adjustments it needs." There are three main factors in the economic growth of each nation: capital accumulation, population growth, and technological progress [2].

Economic growth refers to the expansion of economic activities that result in an increase in the quantity and quality of products and services produced in society, as well as an increase in humanity's prosperity. In the long run, economic growth can be considered as a macroeconomic issue. A country's ability to generate goods and services will improve from one time to the next. This expanded capability is attributable to increasing numbers and quality of manufacturing factors. The investment will result in an increase in capital goods [3]. The technology that is used is changing. In addition, the workforce grows as a result of 
population growth, and workers' skills improve as a result of their job experience and education.

Many factors can affect economic growth one of the factors that affect it is the health index. The health index, projected by life expectancy at birth, can be known through the average delivery and death rate per year. Comparing these variables is expected to reflect the average length of life that people desire in a region. All countries have agreed upon the maximum and minimum values for calculating health. The Healthy Family Index (IKS) is the twelfth calculation of healthy family indicators of each family whose size ranges from 0 to 1 [4]. Families belonging to healthy families are families with IKS $>0.8$ [5]. Life expectancy is an essential indicator in measuring longevity. A person's longevity is a product of the efforts concerned and how far the society or country with the use of available resources seeks to extend the life or life of its population. In theory, a person can survive longer if he is healthy, and when suffering from the illness, he should arrange to help speed up his recovery to stay longer (come to health workers). Therefore, community development is said to have not succeeded if the utilization of community resources is not directed at health development to prevent "citizens dying earlier than they should."

Another factor is education, and there are still obstacles in education in Indonesia that we can look at together at this time, such as the cost of education and educational facilities. The cost of education is a significant obstacle that many Indonesian people complain about today, especially for people from the lower middle class. Educational facilities are also one of the obstacles in education in Indonesia today [6]. The lack of adequate educational facilities dramatically affects the quality of human resources as a generation of nations. Lately, it can be seen on Television reporting the collapsed school building. Of course, it can harm Indonesia itself, reminding those learners are the next generation of the nation.

Another factor is the development of MSMEs. SMEs have an enormous influence on the amount of state revenue. Some types of SMEs become a source of state foreign exchange. In other words, SMEs have become an investment for the country, especially SMEs in agriculture and crafts [7]. The agricultural sector in Indonesia has become one of the plentiful commodities for domestic needs, even as an export commodity for Indonesia. Unlike Indonesian handicraft production, the production of some regions in Indonesia is sold in the domestic market. Still, it has been able to penetrate the world market, especially countries in Asia.[7] In addition to being beneficial for Indonesia's economic growth, without realizing it, SMEs can also reduce the unemployment rate in the community. In contrast, it is improving the level of community welfare.

\section{Library Review}

\subsection{Health Index}

The life expectancy at birth can be known through the average delivery and death rate per year. The comparison of these variables is expected to reflect the average length of life that people desire in a region. All countries have agreed upon the maximum and minimum values for calculating health. The highest number limit calculating this component is 85 years and the lowest at 20 years. This figure is under the standards set by UNDP. Health, according to Law No. 36 of 2009, is a physically, psychologically, spiritually, and socially healthy state that allows everyone to live productively and economically. 


\subsection{Education Index}

The calculation of this index is based on two indicators, namely, Old School Expectations and Average Length of School. Old School Hope numbers are interpreted as hopes that children can take. The number of old school expectations is calculated in children aged seven years and above. Step calculation of RLS by calculating the number of people who according to Calculate the number of residents who are still in school based on their age of 7 years and above. Then, based on the age of 7 years and above, calculate the ratio of residents still in school, as well as the school's old expectations. The education index is used to measure the dimension of knowledge, and it is computed using the number of old school expectations and the average length of time spent in school of school [8]. Here's the description [8]:

a. Old School Hope (HLS), the duration of school (in years) that is expected to be felt by students at a specific age in the future is referred to as old school expectations.

b. Average Length of School, the average length of school Defined as the average number of years spent by residents aged 15 years and above to pursue all levels of formal education that have been undertaken. This indicator is calculated from the highest education variables completed, and the level of education that is being /ever occupied, which is asked on the questionnaire suspends kor.

\subsection{UMKM Development}

The growth of UMKM in Indonesia has had a good impact on economic development. UMKM also has a significant influence on the amount of state revenue. Some types of UMKM become a source of state foreign exchange. In other words, UMKM has become an investment for the country, especially SMEs in agriculture and crafts. In addition to benefiting Indonesia's economic growth, without realizing it, UMKM is also able to reduce the unemployment rate in the community while increasing the level of community welfare [7]. Because the number of UMKM that can employ millions of workers who were initiated into the workforce. That way, the interest of the community will increase and be more secure.

The definition of UMKM in Indonesia is governed by the Law of the Republic of Indonesia No. 20 of 2008 on UMKM. Micro-businesses are productive enterprises owned by people and individual business entities that meet the Law's micro business characteristics, according to Article 1 of the Law. Small business is a compelling economic business conducted by individuals or business entities that are open are subsidiaries or not subsidiaries owned, controlled, or part, either directly or indirectly, of medium or large businesses that fit the small business criteria as defined by the Law [9].

\section{Methodology}

The method used in this study is to use multiple linear regressions. The population of this study is all variable data related to health index, education index, and MSME development to economic growth, which amounted to 5 districts with a period of 10 years so that the population numbered 50 . The sample in this study used saturated pieces, namely the technique of determining components by taking the number of people, then the number of samples as much as 50 . When viewed from its nature, the data used in this study is quantitative in the form of numbers and can be measured. The data used in this study is secondary data, which is data in the form of annuals that have been compiled and published by related parties. The data 
needed in this study is secondary data collected in the form of time series data for ten years, namely from 2010 to 2019 with five regencies so that it numbers 50 .

\section{Results and Discussion}

\subsection{Results of Estimated Panel Data Model}

Based on paired tests of all three-panel data regression models, it can be concluded that the chow test results of the data panel model are better than using common effect panel data. The Hausman test results of the panel data model also show that the better is to use the random effect panel data model and the better test of the multiplier data model (LM) is a random effect. The hypothesis test in this study is better using a random effect model, following the conclusion of the panel data model test [10]:

Table 1. Panel Data Regression Model Testing Conclusions

\begin{tabular}{clll}
\hline No. & \multicolumn{1}{c}{ Method } & \multicolumn{1}{c}{ Testing } & \multicolumn{1}{c}{ Result } \\
\hline 1. & Chow-Test & Fixed vs. Common & Common Effect \\
2. & Hausman Test & Random vs. Fixed & Random Effect \\
3. & Lagrange Multiplier & Common vs. Random & Random Effect \\
\hline
\end{tabular}

\subsection{Results of Panel Data Regression Analysis}

Based on the results of the regression of panel data, the equation is formed as follows: $\mathrm{Y}=67,42501-33,05170 \mathrm{X}_{1}+7,123141 \mathrm{X}_{2}-0,022096 \mathrm{X}_{3}$

The analysis is as follows:

a. The constant value of 67.42501 means that if all paribus cateris variables are worth 0 , the PDRB value will increase by 67.42501 .

b. The regression coefficient value $\mathrm{X} 1=-33.05170$ means statistically that an increase of 1unit variable life expectancy will decrease the PDRB value by 33.5170 .

c. The regression coefficient value X2 $=7.123141$ means that an increase of 1unit of average variables HLS and RLS will increase the PDRB value by 7.123141 .

d. The regression coefficient value X3 $=-0.022096$ means statistically that an increase of 1 unit of MSME development variables will increase the PDRB value by 0.022096 .

\subsection{Simultaneous Test Results (Test F)}

Based on the results of model 1, it can be seen that the value of Fhitung is 8.184661, and Ftabel is 3.19. Fabel is obtained from the numerator value $(\mathrm{k}-1)$ of $(3-1=2)$ and the denominator $/ \mathrm{df}=(\mathrm{n}-\mathrm{k})$, $\mathrm{df}=(50-1=49)$ then obtained Ftabel by 3.19. So it can be concluded that Fhitung $>$ Ftabel then rejects the null hypothesis, which means that independent variables (health index, education index, and MSME development) simultaneously affect GDP (economic growth).

\subsection{Partial Test Results (Test t)}

Based on the table above, the following results of the $t$ (partial) test analysis: 
a) Effect of Health Index on PDRB

Based on the results of the value of the $\alpha=5 \%, \mathrm{n}=50$ and $\mathrm{k}=1$ then $\mathrm{df}=(\mathrm{n}-\mathrm{k})$ is $\mathrm{df}=$ $(50-1)=49$, then ttabel $(0.05 ; 49)=2.00958$ so that the comparison is -thitung $>$-ttabel $1,297139>-2.00958$. Then the probability value on the variable is obtained the value of the health index $=0.2011$, while the standard probability of 0.05 or $5 \%$ so that the ratio of the probability value of the health index $=0.2011>0.05$, so that it is concluded that the health index index index variable does not significantly affect the PDRB variable.

b) Influence of Education Index on PDRB

Based on the results of the value of ttabel with $\alpha=5 \%, n=50$ and $k=1$ then $\mathrm{df}=(\mathrm{n}-\mathrm{k})$ is $\mathrm{df}=(50-1)=49$, then thabel $(0.05 ; 49)=2.00958$ so that the ratio is thitung $>$ ttabel $4.359838>2.00958$. Then the probability value on the variable is obtained the value of the education index $=0.0001$, while the standard probability of 0.05 or $5 \%$ so that the comparison of the value of the educational indes probability $=0.0001<0.05$, so that the index inferred variable significantly affects the PDRB variable.

c) Influence of MSME Development on PDRB

Based on the results of the value of the $\alpha=5 \%, \mathrm{n}=50$ and $\mathrm{k}=1$ then $\mathrm{df}=(\mathrm{n}-\mathrm{k})$ is $\mathrm{df}=$ $(50-1)=49$, then ttabel $(0.05 ; 49)=2.00958$ so that the comparison is obtained that is thitung $>$-ttabel $-0.039005<2.00958$. Then the probability value on the variable is obtained the value of the development of MSMEs $=0.9691$, while the standard probability of 0.05 or $5 \%$ so that there is a comparison of the probability value of the development of MSMEs $=0.9691>0.05$, so that it is concluded that the independent variable of MSME development is not it significantly affects the PDRB variable.

\subsection{Determination Coefficient Results (Adjusted R Square)}

Based on the coefficient of determination results in the table above, the value adjusted R2 is 0.305496 , indicating that the independent variables used in the study, i.e., health index, education index, and MSMEs development, are capable of explaining 30.5496 percent of the dependent variables (PDRB), with the remaining 69.4504 percent explained by variables not included in the research model.

\section{Conclusion}

Based on the analysis, the conclusions of this study are as follows:

a. The health index, education index, and MSME development have a significant influence together on economic growth in DIY Province.

b. The health index did not have a significant negative influence on economic growth in the DIY Province.

c. The education index has a significant favorable influence on economic growth in the DIY Province.

d. The development of MSMEs does not have a positive influence on economic growth in DIY Province.

\section{References}

[1] Lincolin, A. Pengantar Perencanaan Ekonomi Daerah. BPFE, Yogyakarta (2009) 
[2] Todaro, M.P., and Smith, S.C. Economic Development. $11^{\text {th }}$ Edition. Pearson, New York (2012)

[3] Gherghina, S. C et all. Small and Medium Sized enterprises (SMEs): the engine of economic through investments and innovation. Sustainability, Vol. 2020(12), pp. 1-22 (2020)

[4] Bagolin, I. P. Human Development Index (HDI) and its family of indexes: an evolving ctritical review. Revista de Economia, Vol. 34(2), pp. 7-28 (2008)

[5] Ministry of Health. Indonesia Health Profile 2016. (2016)

[6] Ekosiswoyo, R et all. Strategi Akselerasi Pencapaian IPM Bidang Pendidikan Untuk Mendukung Kebijaksanaan Pembangunan Jangka Menengah Kota Semarang. Riptek, Vol. 1(2), pp. 23-33 (2008)

[7] Keskin, $\mathrm{H}$ et all. The Importance of SMES in Developing Economies. $2^{\text {nd }}$ International Symposium on Sustainable Development. June 8-9 2010, Sarajevo, pp. 183-192 (2010)

[8] Badan Pusat Statistik. Potret Pendidikan Indonesia: Statistik Pendidikan 2017. Badan Pusat Statistik, Jakarta (2017)

[9] Tambunan, Tulus T.H. UMKM Di Indonesia. Ghalia Indonesia, Bogor (2009)

[10] Dewi, N. L. S., \& Sutrisna, I. K. Pengaruh komponen indeks pembangunan manusia pertumbuhan ekonomi Provinsi Bali. E-Jurnal EP UNUD, Vol. 3(3), pp. 106-114 (2014)

[11] Benis, A. R. The impact of small and medium-sized entrepreneur on economic growth in iran. Global journal of management and business research, Vol. 14(2), pp. 58-65 (2014)

[12] Digdowiseiso, K. Teori Pembangunan. Lembaga Penerbitan Universitas Nasional, Jakarta (2019)

[13] BPS Indonesia. Data dan Informasi Kemiskinan Tahun 2003.Badan Pusat Statistik, Jakarta (2003)

[14] BPS Indonesia. Pedoman Praktis Perhitungan PDRB Kabupaten/Kota. Badan Pusat Statistik, Jakarta (2008)

[15] Badan Pusat Statistik Provinsi Banten. Pengeluaran dan Konsumsi Rumah Tangga Provinsi Banten. Badan Pusat Statistik Provinsi Banten, Banten (2016)

[16] Badan Pusat Statistik Provinsi Banten. Indeks Pembangunan Manusia . Jakarta : BPS (2019)

[17] Chalid, N. Pengeluaran Konsumsi Rumah Tangga di Daerah Riau. Jurnal Ekonomi, Vol. 18(1), pp. 28-40 (2010)

[18] Dowling, J. M., \& Valenzuela, R. Economic Development in Asia, second edition. CENGAGE Learning, Singapura (2010)

[19] Elistia., \& Syahzuni, B.A. The Correlation of The Human Development towards economic growth (GDP per capita) in 10 ASEAN member country. Journal of humanity and social studies, Vol. 02(02), pp. 40-46 (2018)

[20] Fakih, M. Runtuhnya Teori Pembangunan dan Globalisasi. Pustaka Belajar, Yogyakarta (2002)

[21] Halim, M. A. Teori Ekonomika Edisi 1. Jelajah Nusa, Tangerang (2012)

[22] Hasan, M., \& Aziz, M. Pembangunan Ekonomi dan Pemberdayaan Masyarakat: Strategi Pembangunan Manusia Dalam Persfektif Ekonomi Lokal. CV Nur Lina, Makasar (2018)

[23] Hikmat, H. Strategi Pemberdayaan Masyarakat. Penerbit Humaniora, Bandung (2004)

[24] Iskandar, I. Effect of human development index fund on economic growth through a special autonomy. Jurnal Ekonomi Pembangunan, Vol. 18(1), pp. 40-49 (2017) 
[25] Jhingan,. Ekonomi Pembangunan dan Perencanaan ed.3. Rajawali Press, Jakarta (2007)

[26] Kusumaningrum, R. S. D. Link of Fiscal Decentralization To Poverty Reduction: Indonesian Context. Jurnal Economia, Vol. 9(2), pp. 116-129 (2013)

[27] Lincolin, A. Ekonomi Pembangunan. Unit Penerbit dan Percetakan STIM YKPN Yogyakarta, Yogyakarta (2010)

[28] Lincolin, A. Ekonomi Pembangunan Lanjutan. Universitas Terbuka-Kementerian Pendidikan dan Budaya, Tangerang (2014) 